\title{
Analysis on Income Accounting of Real Estate Enterprises*
}

\author{
Yu Gu, Yanan Yuan \\ Beijing Wuzi University, Beijing, China \\ Email: yyn603374055@163.com
}

How to cite this paper: Gu, Y., \& Yuan, Y. N. (2016). Analysis on Income Accounting of Real Estate Enterprises. Journal of Financial Risk Management, 5, 202-211. http://dx.doi.org/10.4236/jfrm.2016.53020

Received: September 11, 2016 Accepted: September 27, 2016

Published: September 30, 2016

Copyright $\odot 2016$ by authors and Scientific Research Publishing Inc. This work is licensed under the Creative Commons Attribution International License (CC BY 4.0).

http://creativecommons.org/licenses/by/4.0/

(c) (†) Open Access

\begin{abstract}
With the rapid and sustained development of China socialist market economy, the real estate industry has become the industry part that plays a dominant role in national economy. But the related accounting system of real estate enterprise is not perfect in China and fails to have a full range of coverage, so part of the real estate enterprises will take advantage of the system vulnerabilities to do some illegal behaviors, including manipulating profits, whitewash statements and other violations, especially in the case of income accounting. In this paper, by analyzing the reason and current situation that emerges in the income accounting of the real estate industry in our country, here we will put forward corresponding countermeasures on the accounting income of real estate enterprise, in order to ensure the normal operation and management of real estate enterprises, to ensure the interests of investors, then to stabilize the socialist market economy, and to guarantee the formulation of state macro-control policy.
\end{abstract}

\section{Keywords}

Real Estate Enterprise, Revenue Accounting, Countermeasures

\section{Introduction}

The real estate industry is an important industry of the national economy, playing a dominant role, and the national accumulative investment has closed to 10 trillion by 2014 in China. Although China's real estate industry has developed rapidly, it also has caused some problems, and the income accounting problems are more common. Especially after the implementation of new accounting standards, accounting requirements

${ }^{\star}$ Fund project: the Beijing municipal science and technology innovation platform project "business and enterprise service innovation research". 
for real estate enterprises have a new standard. Income accounting problem of real estate enterprise is paramount: it not only relates to the normal operation and management of the company, but also relates to the investors' trust and social moral problems, even to social stability and healthy development of market economy.

\section{Accounting Standard for Business Enterprises-The Income Accounting Rules of Real Estate Enterprise}

China's "Accounting standards for enterprises-basic standards", through the finance ministry no. 33 publishing on February 15, 2006, takes effect from January 1, 2007. On July 23, 2014, according to "the decision on modifying the 'accounting standards for enterprises-basic standards' of the ministry of finance", for income accounting regulation is as follows: 1) Income is defined as: refers to the total inflow of economic benefits formed in daily activities, will lead to increases in owners' equity, and has nothing to do with the owner invested capital. 2) For the recognition criteria of income: income can be confirmed only by the economic benefits that are likely to flow into enterprise assets or debt reduction, and the inflow of economic benefit can be measured reliably. 3) To comply with the definition and recognition criteria of revenue projects, the requirements shall be included in the income statement (The Ministry of Finance, 2006).

For the real estate development enterprise accounting, easy to carry out the "accounting standards for enterprises", the ministry of finance formulated the "real estate development enterprise accounting system". Among them, the caption of account "business income" in no. 501 is used for accounting operating income earned by business through external transfer, sales, settlement and lease development products, as follows: 1) transfer, land sales and commercial housing, all of them should be seen as a sales. When land and commercial housing have been transferred, and have submitted the invoice to settle the bill to the buyer, 2) the agent-construction of housing and project, should be seen as sales when the houses and project completion acceptance, completed the property transfer procedures, and has submitted the settlement bills of project price and construction of housing to entrust unit. 3) For land and commercial housing adopts instalment payment sales approach, can split into account in terms of payment time as stipulated in the contract. 4) Rental product development, shall be as income, after collection of rent on specified date stipulated by the provisions of the lease contract (or agreement); having arrived the receiving date stipulated in the contract and rent party fails to pay the rent, shall be deemed to be business income (Finance, 2010).

On the specific application, first, the operating revenue of the enterprise, should according to the actual cost accounting. Implementation in current business income, debit "receivables", "bank deposits" and other subjects, credited subject. Second, this should set up the subsidiary ledger according to the categories of business income, such as "land transfer income", "commercial housing sales", "facilities sales revenue", "income from settlement of construction engineering", "lease rental income products", etc. Third, in the final, transferring the balance all to "profits this year" course, after carried 
forward, caption of account should has no balance.

\section{Source of Income for Real Estate Enterprises}

Source of income for real estate enterprises, mainly includes the following four aspects:

First, merchandise sales: This enterprise has transferred the main risks and rewards of the goods property to the buyer, the company no longer carries out continuous management right and real control authority concerned to proprietorship the goods, Related revenues can be measured reliably, the sales have received or obtained payment evidence, the related economic interests are likely to flow into the enterprise, and the cost related to the goods can be measured in a reliable way, to confirm the revenue realization.

Second, to provide labor services: The result of service transaction provided on the balance sheet date can be reliably estimate, reliable estimate refers to the amount of revenues can be measured reliably, the related economic interests are likely to flow into the enterprise, the progress of transaction completion can be reliably determined, the cost of trading has occurred and will take place can be measured reliably. In the final, according to the percentage of completion method, service revenue is confirmed.

Third, land development: Commercial land developed by real estate enterprise, we can transfer the land use right. Land development, according to Percentage of Completion Method, confirms the contract revenues and expenses on the balance sheet date.

Fourth, assigning the right to use assets: The economic interests related to trade are likely to flow into the enterprise, and the amount of revenues can be measured reliably. Amount of interest income, according to the time and real interest rates of enterprise monetary funds used by others to calculate and determine. Amount of royalty revenue, in accordance with charging time and methods stipulated by the relevant contract or agreement to calculative determination.

\section{The Revenue Recognition and Comparative Analysis of the Listed Real Estate Companies in China}

By 2014, china has a total of 144 listed real estate companies. Different listed companies use basically the same way for labor income, land development, the patterns of affirmation of the income through assigning the right to use assets, the following are the main types of commodity sales revenue:

First, proceeding revenue recognition after project completion approval (commodity house has been completed, been qualified and has the housing conditions), such as the Financial Street Holding Co. LTD., Shenzhen Special Economic Zone Real Estate (Group) Co. LTD. (Chen \& Chen, 2013).

Second, in the housing delivery time for revenue recognition (real estate developers will consign commercial housing with housing conditions to the buyer, and then to revenue recognition if owner without justifiable reason to refuse to receive, then to written notice that after the determined delivery date for revenue recognition), such as Cofco Property (Group) Co., LTD., Hainan Expressway Co., LTD. (Chen \& Chen, 
2013).

Third, revenue recognition by installments according to the contract, in terms of the fair value of the receivable contract price to confirm by stages, such as Tianjin Real Estate Development (Group) Co., LTD., Jia KaiCheng Group Co., LTD. (Chen \& Chen, 2013).

The above three kinds of revenue recognition ways, each has advantages and disadvantages.

First of all, after the project completion acceptance to proceed revenue recognition, and often the Annual financial just reflects investment costs, making statements fail to reflect actual situation. When all projects of the enterprise under construction are completed, the product conforms to confirm standard and after completion of the acceptance, the previous deposit received will be identified as income. So, this year's revenue will suddenly increase a lot.

Secondly, at the time of delivery for revenue recognition, this kind of patterns of affirmation is similar to one situation. But, by contrast, revenue recognition span is longer, the uncertainty is more obvious (Huang, 2013).

Finally, according to the contract in installment to confirm the revenue, the situation is more common to be seen, essentially embodying the financing nature, or to say to adopt the deferred way. In this kind of revenue recognition mode, there will not emerge large conditions like the first two patterns of volatile situation.

Taken together, the third is called Installment affirm income model that according to contract, revenue recognition is smooth, profits less volatile, this can better reflect the operating performance of the enterprise for investors, creditors and relevant government departments, so as to measure the current financial situation, forecasts the development trend of the future, and then to formulate better development strategy, making the enterprise development to strive for further improvement (Zhang, 2011). It has very important practical significance for the stability of the market economic order and smooth of state macro-control (Ye \& Bo, 2012).

The former two modes, revenue recognition is volatile, profit volatility, the revenues and expenses not matching, income and cash flow is not matching, which causes asymmetric information, the accounting information quality to drop, easy to misleading investors, creditors and relevant government departments, making them difficult to grasp the enterprise's operating ability and financial status, then making the wrong decision, which will affect the normal operation, and even affect the market economic order.

\section{The Suggestion of Income Accounts in Listed Companies}

\subsection{Pointedly Improving and Refining the Laws and Regulations System of Real Estate Enterprises}

Accounting Standards for Business Enterprises does not especially mention the revenue recognition of real estate industry, and in "the Real estate development enterprise accounting system" specially formulated by the ministry of finance, the establishment of 
Income confirmation principle was fuzzy, therefore in the real estate enterprise accounting system remains to be advanced and refined.

\subsection{Enterprises Should Have Multi-Angle Comprehensive Considerations}

The selection of real estate enterprise revenue recognition methods in addition to consider the accounting principle, we also should consider the practice environment, from the current state of the real estate industry and the trend of the real estate market (Chen, 2012). Soaring property prices at present, most of the time the owner can choose payment by installment, in this case to affirm income by installment is more suitable for current situation, and more advantageous to the enterprise development (Qian, 2010).

\section{Conclusion}

Real estate accounting is internal guarantee for the healthy development of real estate. Yet the current form is still not optimistic, the question remains, and the real estate enterprise accounting sales revenue recognition is an important performance. To solve the main problems, affirming income by installment is a good choice. But I believe that the real estate enterprise's development momentum cannot be prevented, and as a new generation of accounting, workers will further improve the real estate enterprise accounting.

\section{References}

Chen, Q. J. (2012). The Theory of Real Estate Development Enterprise Income. Commercial Research, No. 3, 73-75.

Chen, Y. J., \& Chen, X. G. (2013). Real Estate Development Enterprise Accounting and Financial Management. Joint Publishing House of China Business.

Finance (2010). The Accounting Standard for Business Enterprises. Beijing: People's Publishing House. http://baike.so.com/doc/201598-213157.html

Huang, C. Y. (2013). Discussing the Problems and Countermeasures in Real Estate Accounting. Foreign Investment in China, No. 20, 172.

Qian, J. (2010). Problems Existing in the Real Estate Enterprise Income and Cost Accounting and Perfecting Countermeasures. Accounting, No. 3, 90-91.

The Ministry of Finance (2006). The Accounting Standard for Business Enterprises. Beijing: Economic Science Press. http://baike.so.com/doc/5380679-5616953.html

Ye, J. F., \& Bo, Y. (2012). Discuss Revenue Recognition Method. The Friends of Accountant, No. $22,76-81$.

Zhang, T. (2011). Revenue Recognition of Real Estate Enterprises Standard Variance Analysis. Accountant, No. 10, 25-26. 


\section{Appendix}

144 listed real estate companies:

\begin{tabular}{|c|c|c|c|}
\hline Code & Name & $\begin{array}{c}\text { Operating Income } \\
\text { (RMB Ten Thousand) }\end{array}$ & $\begin{array}{l}\text { Growth } \\
\text { Rate (\%) }\end{array}$ \\
\hline 000036.SZ & Hualian Holding Co. LTD. & 9591.5535 & -15.9739 \\
\hline 000402.SZ & Financial Street Holding Co. LTD. & $491,904.4665$ & 13.9338 \\
\hline 000965.SZ & Tianbao Infrastructure Co. LTD. & $35,902.5865$ & -55.8511 \\
\hline 000638.SZ & Wisefund Investment Holding Co. LTD. & 6591.9949 & -30.1670 \\
\hline 600322.SH & Tianjin Real Estate Development (Group) Co., LTD. & $80,289.9414$ & -28.0781 \\
\hline 600007.SH & China World Trade Center Holding Co. LTD. & $109,514.5751$ & 1.3557 \\
\hline 000029.SZ & $\begin{array}{l}\text { Shenzhen Special Economic Zone Real Estate } \\
\text { (Group) Co. LTD.. }\end{array}$ & $114,755.2774$ & 100.2450 \\
\hline 000031.SZ & Cofco Property (Group) Co., LTD. & $278,614.6131$ & 18.4208 \\
\hline 000042.SZ & Continental Holding Co. LTD. & $232,675.8623$ & 72.9541 \\
\hline 000886.SZ & Hainan Expressway Co., LTD. & 9908.8173 & 21.4346 \\
\hline 000909.SZ & Soyea Technology Holding Co. LTD. & $61,693.8930$ & 25.1943 \\
\hline 000918.SZ & Jia KaiCheng Group Co., LTD.. & $211,209.9830$ & -21.5018 \\
\hline 000981.SZ & Millions of the Bank's Shares Holding Co. LTD. & $212,136.5214$ & -19.3988 \\
\hline 000656.SZ & US Shares Holding Co. LTD. & $656,074.3004$ & 50.5475 \\
\hline 000691.SZ & Asia Pacific Industry Holding Co. LTD. & 3342.9578 & 202.5177 \\
\hline 000505.SZ & Pearl River Holding Co. LTD. & $13,611.7829$ & 9.1698 \\
\hline 000514.SZ & Chongqing Development Holding Co. LTD. & $31,926.0845$ & -62.5371 \\
\hline 000526.SZ & Silver Run Investment Holding Co. LTD. & 1253.2677 & 130.2794 \\
\hline 000006.SZ & Shenzhen Zhenye Group A Holding Co. LTD. & $202,261.4400$ & 311.5284 \\
\hline 600113.SH & Zhejiang East Holding Co. LTD. & $11,644.3113$ & -37.6970 \\
\hline 600734.SH & Shida Group Holding Co. LTD. & 5491.5682 & 444.5281 \\
\hline 600604.SH & City North High Holding Co. LTD. & 8048.4188 & 3.9328 \\
\hline 600620.SH & Heaven in Stock Holding Co. LTD. & 2557.0657 & 36.3360 \\
\hline 600621.SH & Huaxin Shares Holding Co. LTD. & $29,854.2679$ & -21.4197 \\
\hline 600648.SH & Wai Gao Qiao Holding Co. LTD. & $352,340.0728$ & 38.8689 \\
\hline 600649.SH & City Investment Holding Co. LTD. & $269,012.9074$ & -8.2955 \\
\hline 600675.SH & Chinese Enterprises Holding Co. LTD. & $127,258.5728$ & 14.2358 \\
\hline 600568.SH & Pearl Holding Co. LTD. & $32,547.4740$ & -34.1925 \\
\hline 600576.SH & Good Home Holding Co. LTD. & 276.4738 & -67.4581 \\
\hline 600383.SH & Gemdale Group Holding Co. LTD. & $808,842.8817$ & -10.9584 \\
\hline
\end{tabular}




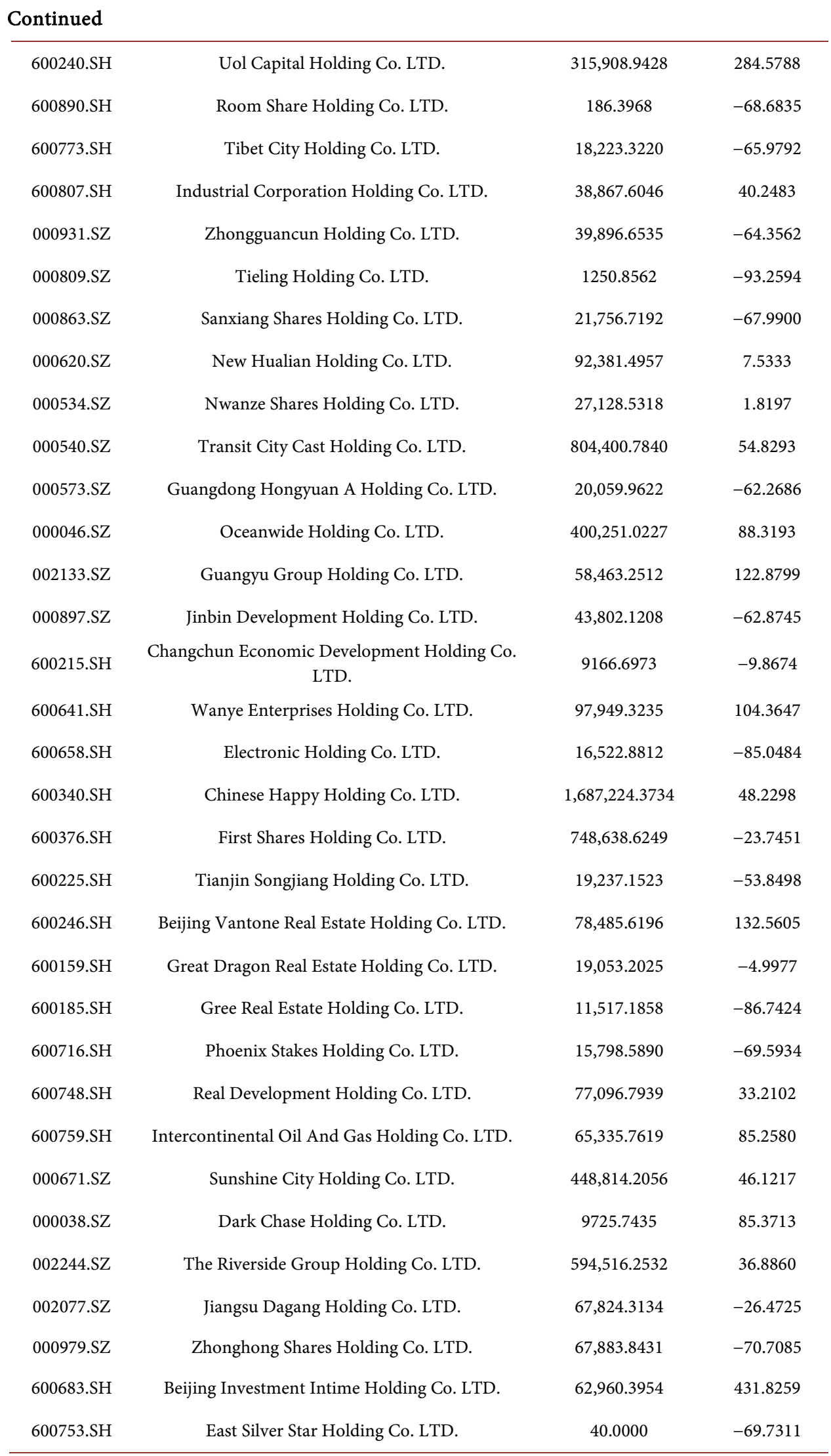




\section{Continued}

\begin{tabular}{|c|c|c|c|}
\hline 600639.SH & Jinqiao Holding Co. LTD. & $74,782.3050$ & -22.2371 \\
\hline 600393.SH & Donghua Industrial Holding Co. LTD. & $29,989.6983$ & 87.2834 \\
\hline 600223.SH & Lushun Real Estate Holding Co. LTD. & $200,466.6534$ & 51.7390 \\
\hline 002208.SZ & Hefei Urban Construction Holding Co. LTD. & $25,260.0695$ & -66.3733 \\
\hline 000668.SZ & Rongfeng Holdings Holding Co. LTD. & 445.9075 & -22.9904 \\
\hline 000670.SZ & Infront Of Micro Holding Co. LTD. & $12,436.1217$ & 93.2005 \\
\hline 000040.SZ & Baoan District Real Estate Holding Co. LTD. & $48,903.2479$ & 44.0638 \\
\hline 000056.SZ & Dark Country Holding Co. LTD. & $17,042.3405$ & 356.2617 \\
\hline 000150.SZ & Yihua Health Holding Co. LTD. & $42,164.1046$ & 430.0929 \\
\hline 000961.SZ & Zhongnan Construction Holding Co. LTD. & $882,100.4573$ & -7.2064 \\
\hline 000024.SZ & Investment Real Estate Holding Co. LTD. & $1,797,394.8437$ & 12.0071 \\
\hline 000090.SZ & Tonge Group Holding Co. LTD. & $273,820.2392$ & 54.0876 \\
\hline 002285.SZ & World-Link Holding Co. LTD. & $191,552.2311$ & 35.2288 \\
\hline 600606.SH & Green Holding Co. LTD. & $8,612,346.0741$ & -26.6700 \\
\hline 600239.SH & Yunnan Quasi-Holding Co. LTD. & $28,211.7571$ & -57.9201 \\
\hline 600158.SH & China Industry Holding Co. LTD. & $26,814.4112$ & -32.3238 \\
\hline 600048.SH & Poly Real Estate Holding Co. LTD. & $4,234,496.1790$ & 24.5465 \\
\hline 600052.SH & Zhejiang Guangsha Holding Co. LTD. & $39,009.1153$ & -15.1465 \\
\hline 600684.SH & Pearl River Enterprises Holding Co. LTD. & $100,360.3157$ & 4.8903 \\
\hline 600732.SH & ${ }^{\star}$ ST New Plum Holding Co. LTD. & 4344.4743 & -60.7150 \\
\hline 002146.SZ & R Development Holding Co. LTD. & $915,221.6167$ & -10.0156 \\
\hline 000797.SZ & China Wuyi Holding Co. LTD. & $100,185.3992$ & 1.2462 \\
\hline 000803.SZ & Kim Car City Holding Co. LTD. & 4550.6358 & -35.7027 \\
\hline 000014.SZ & Shahe Shares Holding Co. LTD. & $18,403.5355$ & -4.2407 \\
\hline 002305.SZ & Southland Real Estate Holding Co. LTD. & $60,476.5306$ & 4.7290 \\
\hline 600895.SH & Zhangjianggaoke Holding Co. LTD. & $50,613.7752$ & -30.1136 \\
\hline 600791.SH & Beijing Energy Real Estate Holding Co. LTD. & $27,127.0343$ & -65.2725 \\
\hline 600724.SH & Ningbo Fuda Holding Co. LTD. & $111,164.8807$ & -69.7109 \\
\hline 600638.SH & New Harbour Holding Co. LTD. & $64,447.8947$ & -5.3746 \\
\hline 600647.SH & Tongda Venture Holding Co. LTD. & 6499.1395 & -0.2402 \\
\hline 600657.SH & Cinda Real Estate Holding Co. LTD. & $216,327.0378$ & 13.4913 \\
\hline 600665.SH & World Source Holding Co. LTD. & $31,611.0374$ & -61.0145 \\
\hline 600533.SH & Qixia Formation In Construction Holding Co. LTD. & $303,759.9070$ & 144.0416 \\
\hline
\end{tabular}


Continued

\begin{tabular}{|c|c|c|c|}
\hline 600325.SH & Hua FA Shares Holding Co. LTD. & $223,252.4299$ & 11.8463 \\
\hline 000506.SZ & Run Resource Holding Co. LTD. & $29,281.7066$ & 74.3019 \\
\hline 000043.SZ & Air Real Estate Holding Co. LTD. & $161,340.7478$ & -17.8980 \\
\hline 600823.SH & Shimao Shares Holding Co. LTD. & $852,604.4247$ & 39.3871 \\
\hline 002016.SZ & Rong Zhaoye Holding Co. LTD. & $61,765.2370$ & 106.8732 \\
\hline 000069.SZ & Overseas Chinese Town A Holding Co. LTD. & $1,016,133.3341$ & -25.2657 \\
\hline 601588.SH & North Star Industrial Holding Co. LTD. & $324,946.6815$ & 25.4670 \\
\hline 600149.SH & Langfang Development Holding Co. LTD. & 138.3147 & -92.9672 \\
\hline 600175.SH & United States Energy Holding Co. LTD. & $239,533.0620$ & 7.2295 \\
\hline 600095.SH & High-Tech Holding Co. LTD. & $10,605.0895$ & -62.8661 \\
\hline 600777.SH & Fashion Industry Holding Co. LTD. & $18,087.1178$ & -60.5677 \\
\hline 000838.SZ & Country Real Estate Holding Co. LTD. & $50,216.1204$ & 50.6579 \\
\hline 600622.SH & Garbo Group Holding Co. LTD. & $103,355.4222$ & 7.7283 \\
\hline 000002.SZ & Vanke A Holding Co. LTD. & $5,026,679.7993$ & 22.7160 \\
\hline 000631.SZ & Shunfa Hengye Holding Co. LTD. & $199,402.6706$ & 80.1200 \\
\hline 000011.SZ & Depth Property A Holding Co. LTD. & $33,876.1310$ & -32.4325 \\
\hline 000502.SZ & Green View Holding Co. LTD. & 1248.0459 & -10.9193 \\
\hline 600745.SH & Zhongyin Shares Holding Co. LTD. & $37,618.0435$ & -50.3763 \\
\hline 600162.SH & Hong Kong Holding Co. LTD. & $186,087.6448$ & 43.6965 \\
\hline 600266.SH & Beijing Urban Construction Holding Co. LTD. & $327,457.8817$ & -7.0524 \\
\hline 000926.SZ & Lucky Star Shares Holding Co. LTD. & $374,675.0917$ & -9.0261 \\
\hline 000609.SZ & Cotton Stock Holding Co. LTD. & 2778.0289 & 63.1192 \\
\hline 000732.SZ & CAC Group Holding Co. LTD. & $416,556.6415$ & 84.8540 \\
\hline 000736.SZ & Real Estate Holding Co. LTD. & $30,778.8893$ & -33.3508 \\
\hline 600555.SH & Dragon Mountain Holding Co. LTD. & 9825.6024 & 1577.2099 \\
\hline 600736.SH & Suzhou High-Tech Holding Co. LTD. & $125,311.3985$ & -16.2466 \\
\hline 600503.SH & Gorgeous Family Holding Co. LTD. & $5,157.6308$ & -80.6082 \\
\hline 000718.SZ & Suning Universal Holding Co. LTD. & $376,389.0483$ & 609.3287 \\
\hline 600767.SH & Wan Shing Medical Therapy Holding Co. LTD. & 1084.9352 & 64.5849 \\
\hline 600463.SH & Airport Shares Holding Co. LTD. & $26,297.0037$ & -30.6622 \\
\hline 000567.SZ & Hyde Shares Holding Co. LTD. & 937.3585 & 422.2696 \\
\hline 000608.SZ & Sun Shares Holding Co. LTD. & $34,324.2000$ & 40.6585 \\
\hline 600743.SH & Huayuan Property Holding Co. LTD. & $218,872.0838$ & -42.7516 \\
\hline
\end{tabular}




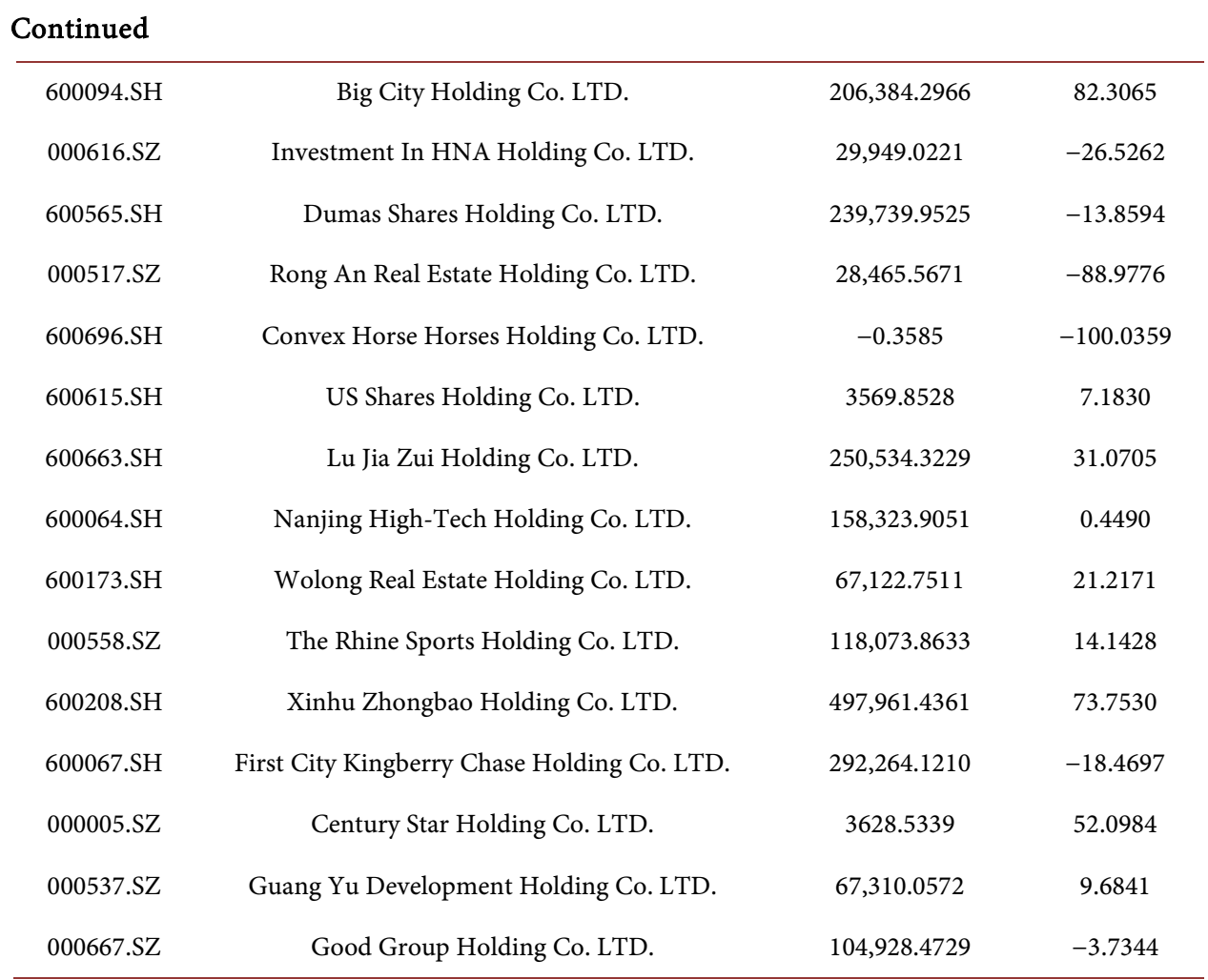

Submit or recommend next manuscript to SCIRP and we will provide best service for you:

Accepting pre-submission inquiries through Email, Facebook, LinkedIn, Twitter, etc.

A wide selection of journals (inclusive of 9 subjects, more than 200 journals)

Providing 24-hour high-quality service

User-friendly online submission system

Fair and swift peer-review system

Efficient typesetting and proofreading procedure

Display of the result of downloads and visits, as well as the number of cited articles

Maximum dissemination of your research work

Submit your manuscript at: http://papersubmission.scirp.org/

Or contact jfrm@scirp.org 